\title{
Richard Nixon's Road to Tehran: The Making of the U.S.-Iran Arms Agreement of May 1972*
}

In May 1972, Richard Nixon travelled to Tehran and signed a deal with the shah of Iran that allowed the Iranian monarch to purchase any U.S. weapons system he desired, in any quantity, short of nuclear weapons. This so-called blank check was a highly irregular move, and a revolutionary change in both general U.S. arms sales policy and in U.S.-Iran relations. It formed the major component of a new U.S. Persian Gulf policy and became a major application of the Nixon doctrine. Exploring the detail of how and why this agreement came to pass and the significant changes it introduced form an important, and so far overlooked, part of Cold War history.

While the importance of the Tehran arms deal is widely accepted among scholars, no study has fully accounted for the detail or broader policy evolution that led to it. Instead, there is a tendency to acknowledge the importance of the meeting itself, yet simultaneously gloss over or oversimplify it. William Bundy asserts that the Tehran meeting was characterized by Nixon "deciding simply" to make a revolutionary agreement with the shah. ${ }^{\mathrm{I}}$ Hanhimäki alleges the opposite, that it was the shah who suddenly took the initiative and "quickly made the most" of Nixon's visit to reorient the U.S.-Iran relationship. ${ }^{2}$ Douglas Little chronicles the changes in Gulf policy under Nixon-yet only offers a short order explanation of the arms deal by stating that Iran was determined to assume its role as a U.S. proxy "sooner rather than later." 3 David F. Schmitz takes a similar path, attributing the policy changes toward Iran to the Nixon doctrine. Yet, he treats the I969-1972 years without distinction, thereby implying

\footnotetext{
* The author would like to thank Steve Marsh, Zach Keck, Adam Groves, and the anonymous reviewers for their valuable feedback in preparing this article.

I. William Bundy, A Tangled Web: The Making of Foreign Policy in the Nixon Presidency (New York, 1998), 328-30. Also see Gholam Reza Afkhami, The Life and Times of the Shah (Berkeley, CA, 2009), 30 I-I6. Afkhami makes a comparatively thorough account of general relations between Nixon and the shah, yet also fails to give any significant detail over the 1972 visit.

2. Jussi Hanhimäki, "An Elusive Grand Design," in Nixon in the World: American Foreign Relations, I969-I977, edited by Fredrik Logevall and Andrew Preston (Oxford, 2008), 38-40.

3. Douglas Little, American Orientalism: The United States and the Middle East Since 1945 (London, 2002), I37-46.
}

Diplomatic History, Vol. 37, No. 4 (2013). (C) The Author 2013. Published by Oxford University Press on behalf of the Society for Historians of American Foreign Relations. All rights reserved. For permissions, please e-mail: journals.permissions@oup.com. doi:Io.I093/dh/dhto26 
that Nixon's arrival in office and the advancement of his doctrine was the change event, rather than other developments. ${ }^{4}$ Finally, various well-known studies have dealt attentively to developments between Nixon and the shah, but lacked access to the archival material that forms the source base of this article. ${ }^{5}$ Each of these accounts feature distortions and omissions that only a close analysis of U.S.-Iran relations, with arms diplomacy as a prime focus, can remedy.

Until the early seventies, policy makers in Washington had been largely unsympathetic toward the shah's plans for hegemonic Iranian power in the Persian Gulf. A policy of limited military (and economic) grant aid to Iran was pursued from $195^{\circ}$ until the mid-sixties. Thereafter the shah began the transformation from military aid to credit purchase agreements as his oil income rose. Yet, there was no appetite in Washington to sell the shah anything more than a fraction of the equipment he wished to buy. From the Truman years, the prevailing wisdom had been to moderate the shah's military ambitions, which were frequently perceived as ruinous to Iran's delicate economic and political stability. As a proAmerican nation in a sensitive geopolitical region, the focus had consistently been on keeping Iran stable rather than strong.

A number of transformative regional events in the late sixties forced U.S. policy makers to change their mind-set. The rise of Arab nationalism and a growing Soviet arms trade with pivotal nations such as Egypt, Iraq, and India introduced volatility into the region. The effects of the Six Day War in 1967 also confirmed that support for Israel was a serious problem in U.S. regional policy. These factors when considered alongside the announcement in January I 968 that Britain would remove its significant military forces from the Gulf in I97 I necessitated a wholesale rethink of U.S. regional policy. The region's oil exports powered Western Europe and Japan. Any prospect of a power vacuum in the wake of the British departure was a serious strategic concern.

Even with the regional unrest and the British announcement in mind, the Lyndon B. Johnson administration (1963-1969) did not unmoor itself from the received wisdom over arming Iran that had existed since $195^{\circ}$. Instead, in the face of extreme and persistent lobbying from the shah, Johnson agreed a series of ad hoc military credit upgrades in 1964 , I966, and I968. These deals were done, reluctantly, merely to keep the shah in the American orbit and not with any distinct strategic solution in mind. ${ }^{6}$ By I 968 , the Johnson administration had realized how few friends the U.S. had in a region that had been suddenly thrust upwards in

4. David F. Schmitz, The United States and Right-Wing Dictatorships, 1965-1989 (New York, 2006), 80-82.

5. See James A. Bill, The Eagle and the Lion: The Tragedy of American-Iranian Relations (New Haven, CT, I988); Richard W. Cottam, Iran and the United States: A Cold War Case Study (Pittsburgh, PA, 1988); Mark J. Gasiorowski, U.S. Foreign Policy and the Shab: Building a Client State in Iran (Ithaca, NY, I99I); and Barry Rubin, Paved With Good Intentions: The American Experience and Iran (New York, I980).

6. See Stephen McGlinchey, "Lyndon B. Johnson and Arms Credit Sales to Iran I 964-I 968," Middle East Fournal 67, no 2 (2013). 
strategic priority. The shah stood as the most staunch and willing regional leader. He repeatedly made it clear through the sixties that the price for his pro-U.S. disposition was advanced military hardware, which he was prepared to pay for. He also made it equally clear on multiple occasions that if he did not get the military credit deals he expected, he would turn to the Soviets for alternatives. ${ }^{7}$ Hence, by Johnson's departure, a pattern of relations had been established of which arms sales, fuelled by a U.S. need to keep the Soviets excluded from Iran, was the currency.

By the time of Richard Nixon's arrival in office in January i969, Iran had already become America's single largest arms purchaser. While this is notable in and of itself, it was the result of an evolutionary process that had been underway for two decades. Nixon did not just change that evolutionary pattern of arms sales with Iran-he completely revised U.S. thinking on Iran's regional role. By the end of his first term in office, Nixon had leveraged U.S. Middle Eastern regional policy primarily around the focal point of a militarily strong, pro-U.S. Iran. In concert, the shah was encouraged to begin an unprecedented military spending spree. It was a win-win solution for both Nixon, and the shah. Nixon achieved a postBritish solution in the Gulf by establishing an Iranian regional policeman, and the shah was finally free to build the military he had fruitlessly coveted for two decades. Consequently, in mid-I972 Iranian annual purchases went, virtually overnight, from being measured in the tens of millions to being measured in the multi-billions.

\section{SETTING THE FOREIGN POLICY AGENDA}

Nixon was an established political operator who came into the White House with a clear desire to exert a personal driving influence in most, if not all, major policy applications during his presidency. In the foreign policy sphere this ranged from opening up China, détente with the Soviet Union, ending (albeit after escalating) the Vietnam War, and diplomatic progress through enduring crises following the I967 Arab-Israeli war. On the very day Nixon took his presidential oath, three directives were issued establishing a new national security system, rebuilt "from the ground up." 8 Nixon wanted to receive multiple options, not for the bureaucracy to expend their effort into hammering out one recommendation, or "papered over compromises negotiated among the agencies at a lower level." 9 Nixon initiated a series of policy reviews based on national security issues. These National Security Study Memorandums (NSSM) drew upon relevant agencies and experts before reporting the possible policy options to the president. Nixon then reviewed the options and adopted a preferred course of action, producing a corresponding

7. Ibid.

8. Kissinger, The White House Years, 23.

9. Draft Paper: United States Foreign Policy in the I97os, December 30, I 969. Nixon Presidential Material, The National Archives II, College Park, Maryland (hereafter NPM). NSC Subject files. Box 325. Folder: The President's Annual Review of Foreign Policy, 2/8/70, Volume I (2 of 3). 
National Security Decision Memorandum (NSDM), which became administration policy.

Through the sixties the shah developed a thesis in which he believed that the Soviets were engaging in "wars by proxy" in Egypt and Iraq in order to gradually encroach upon and disrupt western access to Gulf Oil. ${ }^{\text {Io }} \mathrm{He}$ added that it would be better for Iran to deal with a Vietnam-style situation in the Middle East, rather than repeat a model of American intervention that was clearly failing. Of course, this was designed to complement the shah's longstanding military designs, but his thesis was uncannily perceptive. With this in mind, former American Ambassador to Iran (I965-I969) Armin Meyer, later reflected that "one Tehran visitor upon whom the shah's rationale made an historic impact was former vice president Richard Nixon" " I who visited the shah in 1967.

The Nixon doctrine took shape throughout various speeches and statements in mid-late i 969 before becoming solidified in the publication of a landmark review of American Foreign Policy in February 1970. South East Asia was the catalyst for the rethink. Years of escalating involvement in Vietnam without tangible results had viscerally demonstrated the weakness of blunt force and military intervention. Henry Kissinger noted in July I 969 that it was no longer within the purview of Washington to determine the future of South East Asia, but rather it was desirable that the friendly nations of the region acted dynamically and creatively to develop and maintain an amenable regional structure. ${ }^{\mathrm{I} 2}$ Via Kissinger's account, Nixon spontaneously took forward this line of thinking in a public meeting with the press in Guam, stating that America, "must avoid the kind of policy that will make countries in Asia so dependent on us that we are dragged into conflicts." ${ }^{3}$ Robert Dallek disagrees, noting that Nixon went into the Guam press conference with a privately preconceived and generally complete plan to seize upon global euphoria in the wake of the recent successful moon landing and redirect it toward foreign policy. ${ }^{\mathrm{I}}{ }^{\mathrm{W}}$ Whichever view is correct, the Nixon doctrine soon transitioned to be a global statement of intent for the administration, and Iran would become one of its notable test cases.

The new doctrine was deliberately selective, focusing the bulk of U.S. attention on major areas of importance such as South East Asia. This worked together with the follow-up logic that to remedy such selectivity, capable allies would be urged to make the leap toward self-sufficiency rather than relying on military aid and a guarantee of direct American protection. In that sense, the expectation at the State Department that the new foreign policy doctrine would lead to arms

Io. Armin Meyer, Quiet Diplomacy: From Cairo to Tokyo in the Twilight of Imperialism (New York, 2003), I 39.

I I. Meyer, Quiet Diplomacy, I40.

I2. Kissinger, The White House Years, 223.

I3. Ibid., 224.

I4. Robert Dallek, Nixon and Kissinger: Partners in Power (New York, 2007), I42-43 
limitation in the Middle East was quickly muted. ${ }^{15}$ Instead, the shah finally found fertile ground, together with a clear political will in Washington, for his grand designs as the final draft of the foreign policy review that was published on February I 8, I970 underlined that:

America cannot—and will not - conceive all the plans, design all the programs, execute all the decisions and undertake all the defense of the free nations of the world. ${ }^{\text {to }}$

\section{A NEW FRAMEWORK FOR THE GULF}

A paper was compiled four days after Nixon's inauguration by the NSC, analyzing the Middle Eastern situation and possible policy packages. At this point thinking toward the region was dominated by reflection on Arab-Israeli hostility, which had festered since the Six Day War. The paper was speculative rather than decisive. It pointed toward three essential emphases; to protect Israel, contain any further Soviet influence in the region - which was judged to be far from its potential peak-and finally to prevent any nuclear proliferation in the area. ${ }^{17}$ To replace speculation with policy, NSSM 66 was set into motion on July I 2, I969. The study, titled Policy Toward the Persian Gulf, was intended to form the basis of the answer the Nixon administration would have to the final withdrawal of the British military presence from the Gulf. ${ }^{18}$

The NSSM 66 study group did not actually deliver its report until over one year later, on July 30, I970. The long delay was originally cited as merely unexplained. ${ }^{19}$ Some years later Kissinger cleared up the question of the delay, noting that Cold War concerns about Soviet expansionism were more pressing in the administration's early years than was developing a truly regional focus on the Gulf that incorporated the region's complexities-which Kissinger and his staff did not yet understand. ${ }^{20}$ Without the driving momentum of Kissinger and his

15. William Rogers to Nixon: Suggestions on a Basic Approach for your Review of American Foreign Policy, December 24, I969. NPM, the National Archives 2. NSC Subject Files, Box 35. Folder: The President's Annual Review of U.S. Foreign Policy Vol. I.

I6. United States Foreign Policy for the I970s: A New Strategy for Peace. A Report by President Richard Nixon to the Congress, February 18, I970, 5 (emphases from the original document).

I7. "Basic US Interests in the Middle East," January 24, I969. Via the Digital National Security Archive (hereafter DNSA), Document: PRoo 387 .

I8. Kissinger to Secretaries of State, Defense, Treasury, and the Director of Central Intelligence, "Policy Toward the Persian Gulf," NPM. NSC Subject files. Box 327. Folder: The President's Annual Review of U.S. Foreign Policy 197I (Agency Submissions).

I 9. IG/NEA submitted response to NSSM 66, July 30, I970. NPM. NSDM Working File 2. NPM. NSC Institutional "H" Files. Records of the Staff Secretary (I969-I974). Box H-289. Folder: NSDM 92.

20. See W. Taylor Fain, American Ascendance and British Retreat in the Persian Gulf Region (New York, 2008), 182-83. 
NSC team, the study memorandum lingered on the back burner. It also remained explicit that the British withdrawal would not take effect until the end of I97 I, so there was no urgency to rush to a conclusion.

It fell to the State Department to labor over a new policy for the Gulf. NSSM 66 was an opportunity for the department's Near Eastern Affairs Bureau, led by Assistant Secretary of State, Joseph Sisco, to focus administration attention on the Gulf for the first time. ${ }^{2 \text { I }}$ Sisco, like all of his predecessors, had been on the receiving end of a steady stream of reports from the U.S. Embassy in Tehran going back to the late fifties detailing the shah's increasing malaise over a lack of action on his arms requests in Washington. Although Sisco did not share the shah's conviction that the Arab side of the Gulf would fall due to Soviet stoked Arab nationalism, leaving Iran dangerously exposed, he did understand the necessity of bringing the Shah yet closer into the American orbit.

Three policy options were eliminated at the outset in NSSM 66. The first of those-convincing Britain to reverse its decision to withdraw east of Suez-was abandoned. Two reasons were cited for this, firstly that Britain had proved unwilling to change course, and that "Iran has made clear it wants no foreign military presence in Gulf." The second dismissed option-a dual "hands off" policy to be agreed with the Soviet Union-was rejected due to fears it would "dismay" moderate regimes. Finally, the idea that the U.S. could "stand back" and let events take their course was also dismissed as it would encourage domestic radicalization. The final option would also hinder Saudi Arabia and Iran from playing the active role necessary, since they would be without the American support needed to assert themselves. ${ }^{22}$ The fact that Iran is directly mentioned in two out of these three options as reasons why they are unworkable, signifies the prominence of consideration of the Iranian position in the minds of the study group, and raises the possibility that a clear focus on Iran was a de facto operating principle within the study.

With the former three options dismissed, the study group outlined six remaining options, which finally gained the attention of Kissinger:

(I) Assume the British role

(2) Back a "chosen instrument" (either Iran or Saudi Arabia)

(3) Foster Saudi-Iranian cooperation

(4) Develop significant bilateral relationships with Gulf Sheikdoms

(5) Continue indirect bilateral relationships

(6) Sponsor a regional security pact

As the options were discussed, Kissinger stressed that assuming the British role was out of the question considering the Nixon doctrine. Christopher Van Hollen,

2 I. Ibid, I 83-84; and Sisco to MacArthur, February I9, I970. NPM. NSC Files, Country Files - Middle East. Box 6or. Folder: Iran Vol r. Jan 69 to May 70 (3 of 3).

22. See note ig. 
Sisco's deputy, agreed. ${ }^{23}$ Van Hollen stressed that the third option, Saudi-Iranian cooperation, and eventually a concurrent adoption of the fourth option, bilateral relations, was the preference of the State Department. The Joint Chiefs of Staff concurred. ${ }^{24}$ By October 1970, the six options had been downsized to three due to a broad interdepartmental consensus forming around marrying the middle three options; backing Iran as a chosen instrument, promoting Saudi-Iranian cooperation, and forming bilateral relations with the lower Gulf States. ${ }^{25}$

Concurrently, the CIA delivered a National Intelligence Estimate on Iran in September 1970. It spoke highly of Iran's political stability and rapid economic growth-concurring with steady State Department reports indicating the same. ${ }^{26}$ The report advised that Iran had fairly good relationships with all of its neighbors, excepting Iraq, and that although Saudi Arabia and Kuwait tended to regard Iran as arrogant and condescending; both were broadly acquiescent to its regional ascendancy. The report advised that America was playing a dangerous game by restricting the shah from the military equipment he requested, which would only drive Iran to the Soviet sphere and render the shah unreceptive to future American advice. ${ }^{27}$ The CIA had offered a consistent assessment to this end going back to I 966 after the shah harnessed a thinly veiled brinkmanship strategy with the Johnson administration by courting an advanced arms relationship with Moscow due to Johnson's reticence to equip Iran with a modern air force on favorable credit terms. That strategy had proven highly successful. Between I966 and I968 the shah saw his military relationship with the United States deepen, and his credit line increase, in return for him remaining within the American orbit.

Nixon finally determined in early November 1970 via NSDM 92 that a general strategy of promoting cooperation between Saudi Arabia and Iran was a "desirable basis for maintaining stability" in the Gulf while at the same time, recognizing "the preponderance of Iranian power." ${ }^{28}$ Harking back to the July 30 study memorandum that outlined the six options on the table, the logic for incorporating Saudi Arabia becomes clear. That study clearly addressed Iran as the most powerful state in the region, possessing a capable and willing military force, while at the same time rejecting as "unworkable in practice" any exclusive special relationship with Saudi Arabia. This was chiefly due to the "paramount military position" of Iran, and the folly of not somehow harnessing Iran's position for American interests.

23. Minutes of Review Group Meeting. June 5, I 970 . NPM. NSDM Working File 2. NPM. NSC Institutional "H" Files. Records of the Staff Secretary (1969-1974). Box H-289. Folder: NSDM 92.

24. Ibid.

25. Saunders to Kissinger, October I9, I 970 . NPM. NSC Institutional "H" Files. Records of the Staff Secretary (1969-1 974). Box H-289. Folder: NSDM 92.

26. The State Department produced a Semi-Annual Assessment of the Political Situation in Iran, for one such example, see DNSA: IRoo724.

27. "Iran's International Position," National Intelligence Estimate, Number 34-70. September 3, 1970. DNSA: IRoo738.

28. NSDM 92, November 7, I970. NSDM Working File 2. NPM. NSC Institutional "H" Files. Records of the Staff Secretary (1969-1974). Box H-289. Folder: NSDM 92. 
Conversely, backing Iran alone as a solitary "chosen instrument" would prove a "final straw" for Saudi King Faisal, who was already experiencing extreme discomfort domestically over American support for Israel. ${ }^{29}$ Thus, America risked losing Saudi Arabia from its sphere of influence if it felt that it was being ignored in lieu of its Persian neighbor.

Including Saudi Arabia in the NSDM 92 policy package was therefore, from the outset, more about finding a workable way to facilitate the close relationship with Iran that the White House (and the Shah) desired, than it was the formation of a genuinely balanced policy regarding the two nations. In the words of Harold Saunders, a senior staffer at the NSC, Saudi Arabia "would be the weak link in (the) chain." $3^{\circ}$ Recent scholarship generally concurs that the ensuing pattern of relations validated Saunders" assertion. ${ }^{3 \mathrm{I}}$ Hanhimäki adds that in hindsight, Israel was more accurately a second pillar than Saudi Arabia ever was. $^{32}$ There were no plans for Saudi Arabia to fulfill a regional security role, and it would not be until the Carter administration that the Saudis would receive significant upgrades to their qualitatively and quantitatively meager military. For Nixon, there was "no reason" 33 to back Iran, and not also use American influence to encourage Saudi-Iranian cooperation, amounting to a potential win-win scenario for American interests. But, this was not, and never would be a twin pillars/two pillars policy as it is often referred to in the literature. It was the beginnings of a deliberate policy of producing a single regional security partner of America in the Gulf: Iran.

\section{ARMS: CONTINUITY, NOT CHANGE}

Arms sales under the Nixon administration were initially framed by a verbal and nonbinding promise given to the shah by President Johnson in I 968 for a US\$ I o million credit line per annum from I 969 to I 973 . This came on top of an existing $\mathrm{US}_{5}$ o million credit per annum that had been agreed in I 966 , and the leftovers of the first U.S.-Iran military credit deal which had been agreed in I964. The I964 and i966 deals both expired in I969, leaving the shah a US\$roo million annual credit from I970 onward-equal to where he was in I967. In that sense, the US\$ $\$$ oo million credit deal Johnson gave Iran in I 968 was a top-up credit to allow the shah to accelerate his military upgrade program in the light of regional developments. Yet, from I 969 onwards, there was no existing contractual credit agreement with Iran beyond Johnson's verbal promise.

29. See note i9.

30. See note 25 .

3. See Kourosh Ahmadi, Islands and International Politics in the Persian Gulf: Abu Musa and the Tunbs in Strategic Perspective (London, 2008), 8I-83; and Arshin Adib-Moghaddam, The International Politics of the Persian Gulf: A Cultural Genealogy (Oxford, 2006), I I-2 I.

32. Jussi Hanhimäki, “An Elusive Grand Design,” 26. Also see Trita Parsi, Treacherous Alliance: The Secret Dealings of Israel, Iran, and the U.S. (New Haven, CT, 2007), 30-48.

33. See note 25 . 
Congress approved a total budget of US\$296 million for credit sales in 1969, of which the shah expected his agreed US\$ 50 million from prior deals, ${ }^{34}$ and a second US\$ Ioo million top-up in line with the five-year plan Johnson had indicated in I968. The total US\$ 50 million provision for Iran was therefore over half of the entire allowance set by Congress for global arms credit sales. Despite the significant credit quota that Iran was potentially set to receive, it became clear that the shah wanted much more.

A joint study group was commissioned in May I 970 to assess Iran's long-term military purchase plans after news broke of an Iranian window-shopping spree, which included enquiries on multiple squadrons of French and Soviet fighter jets. ${ }^{35}$ The jets were alternatives to models that the shah had proven unable to purchase in Washington due to his credit limits, and the restrictive ceilings imposed by Congress. In reality, the shah had no intention of purchasing the jets. The entire Iranian air force was built on American foundations and American equipment, with more than twenty years of U.S. aid and investment in place. Added, the shah was a pilot himself and personally coveted U.S. technology. Characteristically, the shah was using thinly veiled brinkmanship to raise high-level attention in Washington. He succeeded. The matter crossed the president's desk via a memorandum from Kissinger who stated:

There seems little reason not to give the shah whatever he wants.... The problem arises as he pushes the limits of his resources and ours. He is understandably a man in a hurry who will press all resources available to their limits. ${ }^{36}$

Kissinger's note was mindful of the reality that when accounting for purchases the shah was seeking, the total expenditure would amount to almost US\$I billion. This was double the existing roadmap that Johnson had loosely left in place in 1968 .

The raison d'être of the study group was, in U.S. Ambassador to Iran, Douglas MacArthur's words, to gently introduce a dose of realism to the shah's appetites. ${ }^{37}$ While Kissinger was displaying a tendency that would come to characterize his

34. It is unclear whether the shah had spent the full \$200 million credit that was set out between 1965 and 1969 by this point. Hence, the maximum figure he had available could have been $\$ 200$ million for 1969 (US\$ Ioo million from I 968 deal, US\$50 million from i 966 deal, and US\$50 million from I 964 deal). However, due to the highly flexible and conditional nature of the I964 and I966 deals and the pattern of arms sales through 1966-1968, I have elected to be conservative and use a US\$ 150 million figure as a realistic guesstimate for the total Iranian spend on U.S. credit for 1969 . It was certainly not less than US\$ $\$_{5} 0$ million.

35. Telegram from MacArthur to Sisco. April 7, 1970. NPM. NSC Files, Country Files Middle East. Box 6or. Folder: Iran Vol I. Jan 69 to May 70 (2 of 3).

36. Kissinger to Nixon. April I6, I970. NPM. NSC Files, Country Files - Middle East. Box 6or. Folder: Iran Vol I. Jan 69 to May 70 ( 1 of 3 ).

37. See telegrams from Douglas MacArthur to William Rogers. March I6, I970 (sections one and two); and May I2, I970. NPM. NSC Files, Country Files - Middle East. Box 6or. Folder: Iran Vol I. Jan i 969 to May I970 (2 of 3); and, telegram from Douglas MacArthur to William Rogers. June 27, I970. NPM. NSC Files, Country Files - Middle East. Box 6or. Folder: Iran Vol 2. June 1970 to Dec 1970 (2 of 2). 
time in office as a strong pro-shah figure, the forces of restraint in arming Iran that dominated thinking in the sixties were still present. As the study group went about its task in Tehran, the State Department's Bureau of Intelligence and Research reported separately that: "There is no immediate military threat to Iran that would justify new inputs of military equipment"; and concluded that:

Iran should be able to maintain its security and to meet any plausible military threat after the I97 I British withdrawal from the Gulf, even at the currently projected levels of armaments based on already existing US arms commitments. ${ }^{38}$

The entire effort of setting up the study group was, therefore, a premeditated drive to expose the shah to the full implications of his plans, and inspire him to calm his military appetite. Nixon's personal concurrence with the initiative ${ }^{39}$ confirmed that there would be no paradigm change in military sales to Iran at this point. In short, this was not reflective of the atmosphere of permissiveness that the shah had expected when Nixon entered office.

As the shah totaled up his latest shopping list-unfazed by the efforts of the study group-intense interdepartmental wrangling in Washington delayed approval for the purchase of two squadrons of $\mathrm{F}-4 \mathrm{E}$ fighter jets. Nixon had given what the shah regarded to be a firm commitment to the sale, which caused an additional headache among the bureaucracy. With the general climate being one of restriction through I970, the shah had taken to petitioning the president himself, as he had done to some success with Johnson in previous years. What the shah did not know was that the Secretary of Defense, Melvyn Laird, had commissioned the CIA to produce a special National Intelligence Estimate to garner an up to date assessment of Iranian security needs, independent of the shah's own impressions. The study concluded that Iran did not need the additional squadrons and was being prematurely pressured into the sale by the manufacturer, McDonnellDouglas. The State Department, which was consistently more accommodating to the shah than any other organ of government in Washington, cautiously supported the sale-noting that some arrangement could be ironed out to allow it. Nixon's personal insistence that the sale continued, together with a reprimand toward McDonnell-Douglas, quelled Laird's objections and ended the interdepartmental impasse. ${ }^{40}$

For Iran, arms purchases required money that could only come from oil. The I 970 Iranian military budget of US\$7 84 million, alone, absorbed over 80 percent

38. “The External Threat to Iran.” June 9, I970. DNSA: IRoo734.

39. See letter from Richard Nixon to the shah, delivered via telegram from Rogers to Embassy Tehran. July 30, I970. NPM. NSC Files, Country Files - Middle East. Box 6or. Folder: Iran $\mathrm{Vol}$ 2. June 1970 to Dec 1970 (2 of 2).

40. See Helms to Kissinger, August I 8, I 970; Memorandum for General Haig from Samuel M. Hoskinson, December 28, 1970; and Memorandums from Harold H. Saunders to Kissinger, November 6, I 970 ; November 4, I970; November 20, I 970; and December I 5, I970. NPM. NSC Country Files - Middle East. Box 6or. Folder: Iran Vol 2, June 1970 to Dec 1970 (I of 2). 
of the entire national oil income for that year-a pattern that was typical of later years. ${ }^{4 \mathrm{I}}$ As the $\mathrm{F}-4 \mathrm{E}$ sale was deliberated in Washington, the shah had been busy renegotiating his oil income to allow for upscaled future arms purchases. The shah had been frequently lobbying the consortium of oil companies present in Iran to both increase production, and increase the levies paid to Iran per barrel of oil extracted. He was also attempting to increase the National Iranian Oil Company's concession within the consortium, which had been set at 40 percent in 1953. Peter M. Flanigan, Assistant to the President for International Economic Affairs, noted that despite the shah's apparent satisfaction with a December 1970 oil settlement which raised production and revenues, “... we will be hearing again from the government requesting that we urge the consortium to provide additional funds." ${ }^{2}$ Flanigan's point was borne out of awareness that the shah had become unswerving in his perception of a dramatically upscaled military as a matter of national security. This could only be realized by either the quantity of oil extracted annually increasing, market price increasing, the Iranian concession increasing further, or a combination of all three.

While it appeared that the shah was battling the same broad framework that he had done in the sixties over arms sales-Nixon had a grander plan underway. In its first two years, the administration had "adopted a low profile" on credit sales, following an approach of merely seeing through previously agreed credit agreements rather than adopting new ones, not wishing to challenge congressional resistance on this issue..$^{43}$ A course correction was effected on April 2 I, I97 I as Nixon sent two bills simultaneously to the Congress; the International Development and Humanitarian Assistance Act, and the International Security Assistance Act, of which the latter dealt with reforming both Foreign Military Sales (FMS) and Military Assistance Programs (MAP). Nixon preempted the delivery of these bills with a presidential directive on March 25, which placed control of all credit sales and foreign aid with the Secretaries of State and Defense, acting under the direction of the president. Reviewing these developments, a joint policy memorandum from the departments of Defense and State noted that:

Where grant aid recipients demonstrate a capacity to meet defense requirements out of their own resources, they will be directed, step by step, to turn to credit programs and other channels to purchase military end-items. ${ }^{44}$

To this point, congress had exercised tight oversight over annual credit sales and military aid, a role that had no place in Nixon's plans. The Senate quickly moved to

4I. Iran Fact Sheet. October 7, I970. Department of State Central Files (Hereafter DOSCF) POL i Iran. Box 9.

42. Flanigan to Nixon. December I, I970. NPM. NSC Country Files - Middle East. Box 6or. Folder: Iran Vol 2, June 1970 to Dec I970 (I of 2).

43. Laird to Nixon, April 9, I97 I. DOSCF DEF i 9 Iran. Box 5.

44. "Joint State-Defense Policy Memorandum on Military Assistance and Arms Transfers," May I 2, I971. DOSCF DEF ig Iran. Box 5. 
form a Select Committee on National Security Policy as part of a concerted effort to check the increasing power of the executive. Hence, Nixon had a battle on his hands, of which MAP was the primary focus. MAP directed taxpayer money to external countries, money that was in demand for domestic programs. MAP spending had been a longstanding bugbear for the congress, which had duly exercised its power by reducing the 1969 and 1970 administration requests by 39.7 percent and 33.I percent, respectively. Prior to Nixon's moves in March and April I97I to focus military spending decisions squarely upon the executive, congress had agreed a comparably equitable i i.8 percent reduction in the administration's I97 I MAP request, appreciating the administration's fiscally conservative request, which at US\$2.2 billion was I 8.5 percent lower than the previous year. Yet, reaction to Nixon's attempt to remove congress from oversight of military spending led to congress chopping 26.5 percent off the proposed 1972 budget for MAP, signaling the clear intent, and ability, of congress to remain involved. ${ }^{45}$ Fortunately for Nixon (and something that would prove significant in time regarding Iran), comparably less scrutiny was directed toward the revised structure for credit sales, which opened up a comparative degree of maneuverability for the executive.

Douglas MacArthur drew attention to the shah's continued press for a full U.S.-Iran arms policy review as he visited Washington to brief a multiple agency group on April 8, I97I. He recommended that the administration should cede to more of the shah's requests for arms, but importantly without going so far as to give him a "blank check." ${ }^{46}$ MacArthur's attention was primarily focused upon facilitating the shah's wish to acquire C-I 30 tanker aircraft, and to replace the bulk of Iran's over Ioo F-5A and F-5B fighter aircraft fleet which it had received the majority of during the sixties as part of its military aid program, with newer F-5Es. This would involve considerable expense, chiefly due to the volume of the sale. The proposals had been rebounding through various agencies in Washington since early I970, and continued to garner indecision into the final months of $197 \mathrm{I}^{47}$

The difficult process of upgrading the shah's air force was exacerbated further by indecision as the shah remained uncommitted to a specific model. He regularly oscillated between various alternatives, including the prohibitively expensive F-I 5 which, if chosen, would be an upgrade of several orders of magnitude technologically. Iranian Embassy Secretary, John H. Rouse, Jr. sent a series of letters to Robert L. Dowell at the Iran desk in the State Department requesting guidance on the F-I 5 to facilitate further discussion with the shah. Replying, Dowell stressed that just two F-I5 squadrons totaling thirty crafts, less than a third of the fleet the shah was looking to replace, would cost approximately US\$600 million. Dowell sarcastically added a footnote to his reply, apologizing for the high

45. Edward A. Kolodziej, "Congress and Foreign Policy: The Nixon Years," Proceedings of the Academy of Political Science 32, no. I (I975): I75.

46. Memcon, "Political-Military Affairs/Iran," April 8, I97 I. DOSCF POL Iran. Box 2377.

47. Rouse to Dowell, November I7, I97 I. DOSCF DEF I 2-5. Box 5. 
price and confirming that the amount was in dollars, not rials. The shah did not share the joke when informed of the price, reacting furiously that America had priced itself out of the market. Understandably, at this point Washington was reticent to encourage the shah to move beyond the $\mathrm{F}-5 \mathrm{E}$. Finance issues aside, the F-I 5 was a generational upgrade in military power that could spark an arms race in the Soviet-aligned nations of the region. Additionally, the advanced nature of the craft was beyond Iranian capability to operate and/or absorb. Under U.S. Air Force instruction, the Tehran Embassy was issued with guidance to discourage any further Iranian enquiries into the F-I $5 .^{48}$

The fact that the shah had in good faith enquired about a craft as advanced as the F-I 5 was a clear sign of a revolution in his appetite for technology. In hindsight, it was also the point at which the Nixon administration began to realize that a similar revolution was necessary in U.S. policy. Failing such a change, American influence over the shah would be at best diluted as he entered into a military relationship with a competitor, or at worst lost as he turned to the Soviets for his advanced hardware. With credit sales still locked into a restrictive yearly ceiling imposed by congress, and the shah's appetites and requests ballooning, an impasse was fast approaching. To put the situation in perspective, if Iran was to skip the $\mathrm{F}-5 \mathrm{E}$ and opt for the F-I 5 , the existing credit ceiling would only allow for six or seven aircrafts-not even half a squadron. Nothing short of a fundamental change in how Washington dealt with arms sales would allow the shah to fulfill his military designs, and also fulfill the general role that the Nixon doctrine and NSDM 92 when viewed together identified for Iran.

\section{THE TEHRAN ARMS DEAL}

On the surface, I97 I was a triumphant year for the shah. He had secured a new oil concession, demonstrated Iranian military strength by occupying the Gulf islands of Abu Musa and Tunbs, and had staged a grand celebration of the 2500 th anniversary of the Persian Empire at Persepolis, which was well attended by world leaders, though noticeably absent was the American president. The outward sense of achievement meant little to the shah, absent the crown jewel of a peerless military power and hegemonic role within the Gulf.

The shah brought matters to a head during a visit by Senator Stewart Symington to Tehran in January 1972 . The senator, who maintained a close interest in arms sales via his role in the Foreign Relations Committee, had requested the visit to assess personally Iran's status as America's largest military credit recipient. Whereas congress had demonstrated a sustained caution toward military sales in general, there was no particular ill will toward the shah at this point on Capitol Hill, although that did begin to manifest in the following years. Symington was delivered a lengthy summary of Iran's regional security concerns: Iraq's continuing

48. See Letters between Rouse and Dowell, May I I, I97I; June I, I97I; July 2, I97I; and July I4, I97I. DOSCF DEF i 2-5 Iran. Box 5. 
Soviet sponsored military buildup, the increasing importance of Gulf oil, the "appalling vulnerability" of Afghanistan and Pakistan — and of course the centerpiece logic that due to the British departure, these problems required upscaled military credit to Iran..$^{49}$ In a watershed moment, via a misplaced gesture of kinship, Symington noted that he would like to see the shah in Washington again; to which the shah "stonily" replied that he thought it was time the president visited Iran.

After Symington's departure, MacArthur cabled back a personal warning to the State Department that the shah, having been snubbed a high-level visit on multiple occasions over recent years, was in a deep malaise, consumed with suspicion that the United States did not regard Iran with much importance..$^{50}$ A presidential visit to Tehran was swiftly timetabled for late May. In addition, the State Department produced a report in late January attempting to predict how best to anticipate the shah's next moves regarding arms. The report anticipated that further upgrades to the Iranian Air Force would shape relations for the near future, and that the shah "increasingly judges U.S. support for Iran by its willingness to supply the arms he wants." ${ }^{\mathrm{I}}$ Therefore, as the administration prepared for Nixon's visit to Tehran, it became explicit that arms would dominate all discussions.

Meanwhile, Iran had diversified its arms portfolio. By I972, Iran was regularly purchasing almost half of its defense equipment from non-U.S. sources, including a broadening arms relationship with the Soviets..$^{52}$ Hence, the shah continued to keep his options open, maintaining the pressure on Nixon to deliver good news when he arrived in Tehran. In one such show, he arranged a visit to Britain in late June to follow Nixon's visit, and made it clear to the British that the visit was to be characterized by defense discussions and that he expected demonstrations "on any British defence equipment in the development phase that might be of interest to Iran." 53

The mood present through the first few months of 1972 left no doubt that Nixon would be inundated with requests for a plethora of America's most advanced military equipment. This would include multiple fleets of the latest F-4 and F-5 fighters; laser guided bombs; state-of-the-art F-I 4 and F- 5 fighters; and Maverick air-to-ground missiles. Nixon was briefed by the Department of Defense to adopt a compromise approach, rejecting any commitment on the laser

49. MacArthur to Rogers. January 5, I 972 . NPM. NSC Country Files - Middle East. Box 602. Folder: Iran Vol 4. Sep I97I to April I973 (3 of 3). Also see Embassy Tehran to the State Department, February 25, 1972. Foreign Relations of the United States 1969-1976, Documents on Iran-Iraq, I969-I972 (hereafter FRUS), Volume E-4, Document i67. 50. MacArthur to Sisco and Rogers. January 5, I972. NPM. NSC Country Files - Middle East. Box 602. Folder: Iran Vol 4. Sep i97 I to April I973 (3 of 3).

5 I. Iran: Arms and the Shah. Department of State Research Study, January 28, 1972. FRUS E-4: I64.

52. CIA Intelligence Memorandum "ER IM 72-79," May i 972. FRUS: E-4: I 8I.

53. HJL Suffield Memorandum (Head of Defense Sales), April I9, 1972. The National Archives of the UK. DEFE 24/1901, E.I80/4. 
bombs due to the U.S. military preferring to retain exclusivity over their use, and to reject any commitment on the F-I 45 and F- 15 s due to priority going to "NATO or other allies and additional requirements of our own." However, it was recommended that he approve the Maverick missiles together with the full allocation of F-4s and F-5s requested. He was also briefed to reassure the shah that despite deep Congressional resistance, the administration would continue to push for an availability of U.S Army technical assistance on the ground in Iran to assist with the integration of its American military equipment. ${ }^{54}$ Hence, the Pentagon wished to effectively retain the restrictionist approach to Iran, allowing him a limited number of replacement jets, yet effectively denying the shah a qualitative upgrade in his fleet.

The State Department also took the opportunity to deliver a lengthy briefing paper to Nixon. The paper recalled the shah's "deep concern" about the growth of Soviet influence in the region. However, rather than respond with a more sober counterpoint as had been the case in the past, the State Department recommended that Nixon concur with the shah's analysis and stress that America fully intends to support its friends in the area "with financial and military assistance and advisors" and express gratification that Iran was ready and willing to play the leading role in regional security. The paper took a much more permissive line on technology transfers than the briefing delivered by Department of Defense. It supported the sale of laser guided bombs, and recommended offering Iran the F-I4 and F-I 5 once they had been fully incorporated into the American military. The overall thesis proffered by the State Department was that experience had shown that the shah responded best when a full and frank disclosure was made to him, and when he was treated as an equal. Anything less led to the feeding of his characteristic paranoia and suspicion. Therefore, adopting a line akin to that advised by the Pentagon would only repeat past mistakes. ${ }^{55}$

The position of the State Department, while consolidating its traditional position of being broadly sympathetic to the shah, was also amplified by increased Soviet penetration in the Middle East, and the ongoing internal weakness of Afghanistan. India and Pakistan, who had been in a protracted conflict over East Pakistan, had gone to war in December 1971. Reflecting Cold War geopolitics, the Soviet Union had provided both political and material support to India, while America (and Iran) backed Pakistan, though only in a tokenistic sense. Pakistan's humiliating defeat in just thirteen days caused widespread fears that the Soviets would gain traction and move south, hence validating the shah's long-held thesis of tangible Soviet designs in the Middle East. Making matters worse, the Soviets had a friendship treaty with Egypt and I5,000 troops on

54. Department of Defense Briefing Papers for the President's Discussions in Iran. May i 8 , 1972. DNSA: IRoo773.

55. Memorandum for the President: "Issues - Talking Points for the Visit to Iran," May 1972. DNSA: IRoo767. 
Egyptian soil; and had signed a similar accord with Iraq in April 1972, with substantial deliveries of advanced weaponry following. As Kissinger put it, American friends in the region were being encircled and a failure to match the influx of Soviet arms "would have accelerated the demoralization of moderate forces in the Middle East and speeded up the radicalization of the area." ${ }^{6}$ Although the Pentagon did recognize that the regional situation was evolving, their own intelligence had reported steadily that a systematic deployment in line with the preexisting credit understanding, rather than a rapid introduction of complex high-tech equipment, remained the most prudent course. ${ }^{57}$ The Pentagon was also understandably sensitive to placing such a plethora of cutting edge American military equipment such as the F-I 5 mere miles from the Soviet border. Regardless of how good an ally the shah was, Iran would still be too weak to successfully repel aggression from the north and prevent sensitive U.S. technology from falling into Soviet hands.

Nixon, with Kissinger by his side, finally landed in Tehran in the afternoon of May 30. The visit came on the back of a triumphant, week-long, high-level summit in Moscow where Nixon and Brezhnev had made further developments in Strategic Arms Limitation Talks, agreed what was known as the Basic Principles of Relations between the two superpowers, and signed the Anti-Ballistic Missile Treaty; a high watermark for Nixon's détente initiative. On the back of an unexpected visit to China three months earlier, Nixon had now completed two major, and quite radical foreign policy initiatives, which opened up space for the sentiments put into motion in NSDM 92 to finally gain some momentum. Quite simply, the timing of the visit to Tehran was no accident, both due to the aforementioned, and due to the fact that it had been recognized that the shah had waited long enough for a dedicated hearing.

Nixon and Kissinger talked candidly with the shah across a laundry list of regional concerns, allowing him the time and space to indulge himself. The discussions ranged from Nixon's consent for setting up Iran as a proxy to get arms into Pakistan to shore it up against India; to the shah's perceived lack of any effect of détente on general Soviet intentions on the Gulf-which remained sinister; to the growing importance of Middle Eastern oil. ${ }^{5}$ With the broader issues in check, discussions moved to the main order of business-arms. Nixon followed the general guidance recommended by the State Department and agreed, in the face of the Pentagon's reluctance, to a specific commitment to sell Iran both the F-I4 and F-I5 as soon as they were ready for production. Deepening the commitment further, Nixon pledged to assign an increased number of uniformed military technicians to Iran, and agreed to the sale of

56. Kissinger, The White House Years, I $263-64$.

57. Gary Sick, All Fall Down: America's Tragic Encounter With Iran (New York, I986), I6.

58. Memcon: Meeting of the shah, Richard Nixon and Henry Kissinger. May 30, 1972. Tehran, Iran. DNSA: KToo5 I 2. 
laser-guided bombs. ${ }^{59}$ The latter caused Laird to scrawl "wow!" upon his memorandum from Kissinger notifying him of the sale. ${ }^{60}$

As the meetings drew to a close, Nixon looked the shah in the eye and said, "protect me," ${ }^{61}$ candidly voicing the Nixon-doctrine-styled role he expected Iran to play upon receipt of its military upgrade. Not only had Nixon agreed to the significant sales outlined above, against the recommendations of his own military, and which would already smash all and any annual credit ceilings with Iran many times over, but he also made a more fundamental commitment to the shah. Nixon gave the shah a personal assurance that no one in Washington would second-guess his needs. Hence, Nixon gave the shah what MacArthur had previously cautioned against; a blank check to indulge himself in any American technology he was willing to pay for in good faith, short of atomic weapons. ${ }^{62} \mathrm{Within}$ formal meetings that lasted no longer than two and a half hours, the shah had gained the ultimate prize that had eluded him for two and a half decades. On that summer evening in Tehran, a truly new paradigm in the relationship between Iran and America had been established.

As many observers have noted and history has taught, the fact that a president decrees something is not often enough for it to transcend resistance from the myriad of governmental organs in Washington. Hence, the real interest in the Tehran arms deal is not just that it happened, but also in bow it became a reality. Mere days prior to the Tehran visit, Nixon reprimanded Kissinger and his deputy, Al Haig, noting his disgust with the "consistent failure to carry out orders" through the various agencies of government. Nixon noted that he expected that from that point onward, Kissinger and Haig would "ride the departments hard" to the effect that if any deviation in the president's orders was identified, Nixon would waste no time disciplining rank and file civil servants. Instead, he would indiscriminately remove "the man at the top." ${ }^{63}$ With Nixon's pugnaciousness filtering through, executive policy became a matter for implementation, not debate, rendering any likely opposition moot via widespread fear that one's job may be forfeit. ${ }^{64}$ Referencing the former, in late July, Jack C. Miklos, the State Department's Country Director for Iran, noted the State Department's satisfaction with the promptness that Kissinger had issued "everyone his marching orders" to facilitate the various agreements reached in Tehran. ${ }^{65}$ Nixon had succeeded by sheer force of will to push his paradigm change for Iranian military relations into reality.

59. Kissinger to Rogers and Laird (State Department copy). June I5, I972. DNSA: IRoo776.

60. Kissinger to Rogers and Laird (Department of Defense copy). June I5, I972. DNSA: IRoo776.

6r. Memorandum of Conversation (Nixon, Kissinger and the Shah). Tehran, May 31, I972. FRUS, Vol. E-4, Doc 201.

62. Kissinger to Rogers and Laird. July 25, 1972. DNSA: IRoo 782.

63. Nixon to Kissinger and Haig, May I 9, I 972 . NPM. NSC Subject Files. Box 341. Folder: HAK/President Memos I97 I ( I of I).

64. Rubin, Paved With Good Intentions, I $34-35$.

65. Miklos to Heck. July 26, I972. DNSA: IRoo 784. 
And, he had done so in less than eight weeks, with his reprimand for Kissinger and Haig having been a timely, and effective injection of presidential willpower.

The final piece of policy in reshaping the arms relationship with Iran was put in place via NSDM I 86. The foundations that NSDM 92 laid down were general rather than specific. They indicated a broad strategy for the Gulf, centered on a potentially strong Iran. What NSDM 92 failed to do was answer the lingering arms credit purchase question. NSDM I 86 directly addressed this issue. Thus, NSDM 92, Nixon's directive taking control of credit sales from Congress, the Tehran agreement, and NSDM I 86 together shaped a comprehensive, and wholly new American strategy toward Iran.

NSDM I 86 was the result of presidential approval of a report delivered on July I 2, I 972 by an NSC-led Under Secretaries' Committee, which had been directed to commence the report in November 1970 following the conclusion of the review into American policy in the Gulf via NSDM 92. Nixon, in line with the recommendations laid out in the report, directed that the provision of military equipment to friendly states of the Gulf would be provided in "reasonable amounts" via both commercial or private channels, and direct government sales via the Foreign Military Sales Act, and tailored to "meet their security needs." siderable evolution in the tone and emphasis of regional arms policy. The Johnson administration, and indeed all prior administrations in the Cold War era, had sought to keep a tight harness on the sale of arms and impress what it thought was the security needs of the country in question, while generally reacting to events in an ad hoc nature. Nixon's revised approach was effectively indicating the reverse, and was a plan for "an active and imaginative direct role" ${ }^{67}$ in the geopolitical contours of the region.

NSDM I 86 therefore ended any speculation over what the future role of arms sales in the Persian Gulf would be. As Kissinger noted in a memorandum to Nixon, "the basic decision is whether to supply or not," with concerns not primarily being upon arbitrary quotas imposed by congress, but rather in "making sure that our sales are understood by our friends and are consistent with the broad regional cooperation we are encouraging. ${ }^{168}$ For the shah, this was the final reassurance he needed, even though the policy was not directed primarily toward Iran and rather toward the smaller states of the region. The personal assurances on enhanced arms sales delivered by Nixon on his visit to Tehran were now backed with a series of presidential directives, and were consistent with policy via NSDM I86. The coming together of the policy package, reflected by NSDM I86, would mark the beginning of a tidal wave of Iranian purchases.

66. Kissinger to the Secretary of State, Secretary of Defense and the Chairman of the NSC Under Secretaries" Committee, August I8, I972. NPM. NSC Institutional ("H") Files. Records of the Staff Secretary (1969-1974). Box H-292. Folder, NSDM I86.

67. Ibid.

68. Kissinger to Nixon, August I4, I972. NPM. NSC Institutional ("H") Files. Records of the Staff Secretary (1969-1974). Box H-292. Folder, NSDM I86. 
Reflecting on the game-changing nature of Nixon's policy on arms sales, Gary Sick, who would go on to serve in the NSC from I974 to I98I as the principal aide for Persian Gulf affairs later remarked:

There was no precedent in U.S. history for an order directly from the President to the national security bureaucracy instructing it to rely on the judgement of a foreign leader in making decisions on arms transfers. ${ }^{69}$

Nixon's ability to march the various organs of government into line was impressive. Though, more impressive was his ability to ensure congress was unable to mount any effective opposition. In Senator Frank Church's words, congress had been reduced to "impotence" in the early seventies with Nixon acting as a thinly masked "autocrat supreme." 70 Nixon's antagonism toward congress over a wide range of policy issues left it temporarily disorientated and disorganized with respect to fulfilling any oversight role of note in policy toward Iran. In fact, congress was not even informed of the revolutionary shift in arms policy that had occurred in Tehran. The full nature of what transpired was not fully understood on Capitol Hill until years later. The introduction of the controversial April I 97 I presidential directive on credit sales and military aid had served its purpose. Congress had been removed from the equation, at least in the short term. As a result, Nixon overruled the congressionally imposed annual credit sales ceilings to make way for the vital component of his foreign-policy doctrine-dramatically increased military sales to selected allies. Although congress would regain its momentum in the years to come- the new pattern of relations with Iran, and heightened credit sales in general, became quickly institutionalized in Washington.

\section{A NEW ERA}

The Nixon years started off slowly with respect to the issue of arming Iran. For the bulk of Nixon's first-term developments appeared largely evolutionary. However, this masked the revolutionary turn that was underway in both Iran arms policy and U.S. Gulf policy. It would not be until Nixon's Tehran meeting with the shah in May 1972 that the full extent of the picture would begin to emerge. The Nixon doctrine, the changes to the Foreign Military Sales procedure, and NSDMs 92 and I 86 finally clicked together into a coherent package when considered alongside the centerpiece of the Tehran arms deal. Following his meeting with Nixon, the shah of Iran found himself wielding a blank check to purchase whatever arms he deemed necessary, and entrusted with the defense of the Gulf.

The extent of the floodgates that Nixon had opened was dramatic. The shah embarked on a titanic shopping spree, ordering close to $\mathrm{US}_{3.5}$ billion in military hardware between July and November $1972 .{ }^{7 \mathrm{I}}$ To put the figure in perspective,

69. Sick. All Fall Down, 22.

70. Remarks of Senator Frank Church in the U.S. Senate, June 3, I970. Frank Church Papers. Series 2.2, Box 39, Folder io.

71. Heck to Miklos. November i I, I972. DNSA: IRoo79o. 
it was more than the annual U.S. bill for military assistance to all of its allies. Yet the shah was only getting started. In early November 1972 he made a major speech in which he set out an intention to increase Iran's naval striking power and extend Iran's defensive frontiers beyond the Gulf. ${ }^{72}$ The nature of the shah's behavior, and the continued flood of arms purchases into I973, confirmed without any doubt that the agreement of May 1972 was not just a noteworthy single event. By removing U.S. firewalls over Iranian credit and reconciling the decades-long divergent perceptions over the role Iran should play in regional security, Nixon revolutionized U.S. policy toward Iran and set forth a new era of relations. From mid-1972 until the shah's final months in power during the winter of $1978-1979$, multibillion dollar annual arms sales would become a characteristic and enduring fixture in U.S.-Iranian relations.

72. Telegram from Embassy Tehran to the State Department, November 7, I972. DOSCF Pol I5-I Iran Box 2379. 